\title{
Machado de Assis e o teatro: um caso de amor
}

Franceli Aparecida da Silva Mello I UFMT

Resumo: O teatro foi uma das primeiras paixões literárias de Machado de Assis. Por ele, debateu-se na imprensa, no Conservatório Dramático, como dramaturgo e como escritor. Neste trabalho procuro demonstrar em que momentos e em que medida se deu o engajamento de Machado de Assis na luta pela modernização da sociedade brasileira através do teatro.

Palavras-chave: Literatura brasileira; Teatro; Machado de Assis.

\begin{abstract}
"O teatro, esse primeiro amor de todos os espíritos poéticos, fascinou Luciano. Os atores e as atrizes pareciam-lhe imponentes personagens; não acreditava na possibilidade de transpor os bastidores e de os ver familiarmente. Esses autores dos seus prazeres eram para ele criaturas maravilhosas, que os jornais discutiam como aos grandes interesses do Estado."
\end{abstract}

Desde muito jovem Machado de Assis demonstrou interesse pelo teatro. Os versos dedicados à cantora Charton e às atrizes Ludovina Moutinho, Luísa Amat e Gabriela da Cunha registram sua admiração pela gente do palco. Admiração que, suspeita-se, extrapolava a esfera profissional.

1. BALZAC, 1981, p. 113 . 
Seus Versos a Corina, provavelmente Gabriela da Cunha, provocaram os ciúmes retroativos de Carolina. Lúcia Miguel Pereira alude a uma suposta paixão por Aimée ou outra "desconhecida”; esta última Raimundo Magalhães Jr. suspeita ter sido Inês Gomes, atriz sem grande projeção do Teatro Recreio Dramático. O autor também aventa a hipótese de ter sido a atriz Ismênia dos Santos, a mulher casada à qual Sizenando Nabuco fez menção em carta ao amigo, em abril de 1864: "Machadinho, [...]. Apesar de apaixonado foste pontual. [...] Creio que houve grande leilão de paixões; e este ano já te vi arrematar uma, que deve-te ser um pouco pesada - menos que aquele marido, mais do que as minhas maçadas." JeanMichel Massa nega essa possibilidade.

Porém tudo isso não passa de especulações. De concreto tem-se apenas a confissão de que Machado substituíra um dos cavalos do carro da cantora lírica Augusta Candiani, num arroubo de entusiasmo juvenil.

Ainda que sua relação com as atrizes nunca tenha atingido o nível de intimidade sugerido por alguns de seus biógrafos, não se pode negar que o teatro e os atores marcaram indelevelmente a vida de Machado de Assis.

Nas crônicas d'A Semana do jornal Gazeta de Notícias, feitas já na sua velhice, o autor recordava saudoso os velhos tempos. Confessava que se regalara em criança com o Antonio José (crônica de 25/8/1895), e na adolescência, com as peças de Dumas Filho e Augier (crônica de 1/12/1895). Entre as lembranças da juventude evocava o Alcazar em vários momentos. Numa crônica de 12/2/ 1893 relatou um sonho de que havia morrido. A caminho do céu, lembrandose de alguns episódios do passado, fala do entrudo, de seu antecessor e do Alcazar Lírico: "Evohé! Bacchus est roi! dizia o coro de não sei que peça do Alcazar Lírico, - outra instituição velha, mas velha e morta. Ficou o coro com esta simples emenda: Evohé! Momus est roi!"

Num folhetim de 23/6/1895, após a leitura do anúncio da representação da comédia Artur ou dezesseis anos depois, pela companhia Fênix Dramática, o cronista reporta-se aos tempos de menino, recordando-se dos antigos teatros, atrizes e peças. Informava que o Ginásio Dramático fora transformado em loja de tecidos, fazendo ainda outra referência ao Alcazar, que naquele tempo lançava modas:

2. MAGALHÃES JR., 1958, p.320-331. 
A cançoneta, como gênero, nasceu no antigo Alcazar. A princípio as cantoras levantavam uma pontinha de nada do vestido, isso mesmo com gesto encolhido e delicado. Anos depois, nos grandes cancãs, mandavam a ponta do pé aos narizes dos cantores. O gesto era feio, mas haviam-se com tal arte que não se descompunham, posto se lhes vissem as saias e as meias - meias lavadas. ${ }^{3}$

Este final, parodiando a carta de Pero Vaz de Caminha, pode ser interpretado como uma referência ao descobrimento. Machado, parece-me, ficou tão perplexo ao descobrir, ou ao ver descobrirem-se, as dançarinas do Alcazar quanto Caminha, com a visão da nudez de nossas índias.

Mas o teatro não era apenas uma lembrança do passado. Em crônica de 13/12/1896, comentando o veto do prefeito do Rio de Janeiro aos impostos sobre companhias teatrais o autor retomou a abordagem de 1858, qual seja, a de taxação das companhias estrangeiras e isenção das nacionais, numa demonstração de que não perdera o interesse pelos destinos do teatro nacional.

$\mathrm{Na}$ juventude, engajar-se no movimento de reabilitação/criação do teatro no Brasil foi a maneira mais contundente encontrada por Machado de demonstrar tal interesse. Para tanto não mediu esforços, atuando em várias frentes.

Um dos traços mais característicos do século XIX foi a influência do jornal diário sobre as sociedades. Como homem de seu tempo, Machado sabia disso e não hesitou em utilizá-lo como instrumento para divulgação de suas idéias sobre democracia, progresso e teatro. Sua admiração pela imprensa diária pode ser avaliada pelo tom laudatório dos ensaios "O jornal e o livro" e “A reforma pelo jornal”, ambos de 1859:

O jornal é a verdadeira forma da república do pensamento. É a locomotiva intelectual em viagem para mundos desconhecidos...;

$\cdots$

... o jornal é uma expressão, é um sintoma de democracia; e a democracia

é o povo, é a humanidade. Desaparecendo as fronteiras sociais, a humanidade realiza o derradeiro passo para entrar no pórtico da felicidade, essa terra de promissão. ${ }^{4}$

3. MACHADO DE ASSIS, 1992, Vol. 3, p. 659.

4. MACHADO DE ASSIS, 1992, Vol. 3, p.945-948. 
Além disso, acrescentava, o jornal promovia a discussão, condição essencial para a democracia.

Naquela época Machado de Assis era um romântico e, como tal, formou na ala dos liberais, criticando os fatos segundo o ponto de vista liberal. ${ }^{5}$ Barreto Leite Filho vai mais longe: para ele, mais que um liberal, o jovem explosivo reagia como um radical típico do século XIX, atacando com desconcertante atrevimento tudo quanto lhe passava pelos olhos.

Há um certo exagero nessa última afirmação, mas nem tanto. No ensaio "A comédia moderna", publicado na Marmota Fluminense, apesar dos equívocos assinalados por Jean-Michel Massa, Machado já ousava discordar do seu chefe (Paula Brito) quanto aos elogios à cena brasileira e das idéias predominantes sobre teatro, numa demonstração de independência e coragem. Foi também nesse jornal que publicou sua primeira comédia - Hoje avental, amanhã luva -, na qual se mostrava bastante simpático à idéia liberal da ascensão social por merecimento.

Em 1858, o autor ingressou no Correio Mercantil como revisor de provas. Embora sua função fosse ínfima, ou melhor, exclusivamente técnica, o convívio com jornalistas de oposição certamente estimulou seu espírito combativo, aberto a novas idéias. Nessa época conheceu Charles Ribeyrolles - um exilado francês, republicano -, com quem, segundo Jean-Michel Massa, provavelmente discutia as obras de Renan, Victor Hugo e Pelletan. Simultaneamente colaborava no Paraíba, de Petrópolis, outro órgão comandado pelos liberais.

Mas foi a partir de seu ingresso no jornal O Espelho, em 1859, que teve oportunidade de dedicar-se mais ao assunto de seu coração. A oferta para fazer a seção Revista dos Teatros foi-lhe providencial, pois, além de freqüentar gratuitamente os espetáculos, podia fazer-se ouvir a partir de uma condição respeitável, a de cronista com direito a cadeira reservada: "Lá estive no posto oficial que me confere o cargo de cronista e pude embeber-me, como todos, em um 'mare magnum' de emoções novas." (os grifos são meus)

Naquele tempo a cena tornou-se lugar preferido para os ataques à sociedade. Na Revista dos Teatros Machado batia-se pela implantação do

5. Cf. BROCA, 1957.

6. Cf. BARRETO FILHO, 1947.

7. MASSA, 1971, p.180-1. 
realismo francês em nossos palcos. Desse modo, ou seja, utilizando-se do jornal para disseminar os preceitos de uma escola que se caracterizava pela discussão dos problemas sociais, cumpria exemplarmente seu dever para com o ideal que abraçara.

Discípulo confesso de Victor Hugo - "...eu tenho a arte pela arte, mas a arte como a toma Hugo, missão social, missão nacional e missão humana." -, nunca deixa de chamar a atenção para o conteúdo liberal das peças que analisava na sua seção de crítica teatral.

Ao comentar Mães arrependidas (CT, pp.124-131), de Mallefille, o cronista mostrava-se incomodado com a punição, excessivamente rigorosa, ao plebeu ambicioso, cujo único bem era o talento: “... o conde Regis não tinha necessidade de matar Arthur, cujo único crime era pretender a mão de Cecília, como ele. Onde assistiam mais direitos?". Ele "se esquecia", porém, de mencionar dois detalhes importantes: Cecília amava Regis; e Arthur via no casamento rico um recurso para atingir uma posição. Machado não interpretava a situação como um conflito de sentimentos, como talvez pretendesse o autor da peça, mas como uma luta de classes em que, anacronicamente, a aristocracia sairia vencedora. É interessante observar como ele assumiu a defesa de Arthur, rapaz interesseiro (um caça-dotes), chantagista, impostor e jogador, tratando-o como vítima de uma sociedade que, por não reconhecer o talento, obrigava os jovens ambiciosos a atitudes moralmente condenáveis. É verdade que, ao final, Arthur se arrependeu de seus atos, mas não era isto o que prendia a atenção do crítico e sim a injustiça cometida contra um jovem talentoso.

Se o Sr. Mallefille reconheceu, como eu, a inconveniência ou pelo menos a desnecessidade de fazer sucumbir Arthur, não sei qual o motivo por que dá esse remate à sua peça; não quero crer que pretendesse manifestar assim a superioridade do barão sobre a casaca do filho da modista. Deve conhecer a índole do século.

Haveria aí um embrião de Guiomar, Iaiá Garcia e Capitu?

Machado ressaltou também o caráter social de algumas composições de César de Lacerda (CT, p.139-141):

8. MACHADO DE ASSIS, 1944, p.132. De ora em diante referido como CT, entre parênteses, ao lado do trecho citado. 
Na Probidade é uma criatura ideal, Henrique Soares, protestando contra as superioridades obrigadas, e o talento honesto menoscabado em proveito da parvoice; nos Dous mundos é um paralelo frizante entre a aristocracia e a classe ínfima, entre o salão e a oficina; entre a casaca e a blouse, entre a luva e o martelo. Toda a vantagem fica ao mundo das pobrezas honestas;

o autor mostrava, porém sem muito entusiasmo: "É uma novidade velha, mas as novas não são comuns nessa época."

É claro que um conteúdo liberal numa peça agradava ao crítico mas isso não era garantia da sua aprovação total; para que tal ocorresse, ela deveria passar pelo crivo da análise formal. Isso ficou bem claro, por exemplo, em seu comentário acerca de Pedro, de Mendes Leal Júnior:

Casa-se perfeitamente ao meu espírito a idéia vigorosa d'essa bela composição. Separo-me talvez em alguns pontos na maneira de vestir o pensamento. $\ldots$

O nome ilustre de um conde que cai para dar lugar ao nome do talento obscuro que se levanta, é o pensamento do drama e constitui para mim um símbolo. É a democracia do talento que reage sobre a nobreza do brazão, um elemento poderoso que procura suplantar uma força gasta”. (CT, p.155)

E neste outro, sobre Feio de corpo, bonito n'alma, de José Romano: "Escrita debaixo de um sentimento liberal ... nem assim o Sr. José Romano conseguiu fazer uma obra completa. Adivinha-se a substância, mas a forma é mesquinha demais para satisfazer a crítica." (CT, p.100-1)

Embora Machado de Assis não ocultasse suas convicções ideológicas, em sua crítica teatral não era muito comum elas serem tão explicitadas como nos exemplos acima. Na maioria das vezes tais convicções apareciam com discrição. Compare-se seu comentário sobre o drama abolicionista Haabás com o de um outro crítico da época: “... é uma bela idéia mal afeiçoada e mal anunciada...”; [...] "O intento foi nobre, e não lhe diminui o alcance moral a rusticidade da forma;..." (Diário do Rio de Janeiro, 2/3/1862), e, "Haabás é um grito contra a escravidão, é um protesto santo e justo contra a usurpação consagrada sob o título de direitos."

9. PESSANHA PÓVOA, 1954, p. 884. 
Foi também n' O Espelho que Machado de Assis publicou suas Idéias sobre o teatro: uma série de artigos cuja terceira parte é dedicada à apreciação do Conservatório Dramático.

Liberal convicto, condicionava o progresso artístico - e não só ele - à liberdade de expressão. Considerava a censura exercida pelo Conservatório extremamente prejudicial ao desenvolvimento da arte. Entretanto, ao contrário dos radicais que pediam o fim da instituição, reconhecia a sua utilidade, e mesmo a necessidade de um órgão que zelasse pela moral e pela qualidade literária do teatro. Quando, em 1862, passou a integrar o grupo de censores do Conservatório, embora seguisse o regulamento da casa, detinha-se mais na apreciação estética das peças. Ao agir assim, acreditava estar contribuindo para a criação de um teatro nacional de qualidade.

Se n'O Espelho Machado teve oportunidade de publicar seu projeto de reforma do teatro brasileiro, foi no Diário do Rio de Janeiro que se tornou verdadeiramente um intelectual engajado.

O Diário do Rio era uma escola de liberalismo. Lá, sob as influências de Saldanha Marinho e Quintino Bocaiúva, o crítico iria alistar-se nas fileiras da política partidária. Seus colegas estavam diretamente envolvidos na campanha eleitoral de 1860 e isso também absorveu as atenções do novo contratado. Chegouse até à indicação de seu nome para a Câmara de deputados, mas foi retirada.

Como em qualquer jornal da época, no Diário o jornalista fazia de tudo. Além de ter assinado três ensaios na coluna Revista Dramática, Machado escreveu na seção Comentários da Semana, mais voltada aos assuntos políticos. Entretanto, nunca deixou de mencionar o teatro, quer para reivindicar apoio do governo aos artistas, aos empresários, à criação de uma escola normal de artes dramáticas (Diário, 16/12/1861), quer para apoiar as tentativas de reorganização do Ginásio em 1861 e 1864, ou ainda para manifestar seu aplauso aos novos talentos. Foi no Diário que defendeu com veemência a História de uma moça rica, do colega Pinheiro Guimarães, contra os "beatos" que obstruíam o caminho da civilização.

O autor também utilizou-se das páginas da Semana Ilustrada, do Futuro e da Imprensa Acadêmica para assuntos teatrais. Também é possível que tenha colaborado com algumas crônicas no Bazar Volante. Porém, excetuando-se os atrevimentos do Dr. Semana (pseudônimo usado na Semana Ilustrada), nesses periódicos não se flagravam mais ousadias ou palavras de ordem; a euforia fora substituída por um discurso mais sóbrio, contido. 
Certamente foi o desejo de contribuir para a criação do teatro nacional o principal responsável pelas incursões de Machado de Assis no terreno da dramaturgia. Porém creio que se deve somar a isso uma série de motivações pessoais, além das já mencionadas no início deste artigo.

Como todo jovem literato do seu tempo, Machado também acalentava o sonho dourado de fazer sucesso como dramaturgo (Alfredo Pujol). Além disso, a possibilidade de se aproximar das atrizes famosas tornava a atividade mais atraente (Mário Matos).

Para Joraci Camargo o teatro teria sido uma arma ao mesmo tempo de defesa e de ataque do jovem escritor na luta pela conquista de uma posição social. Em artigo para a revista Dom Casmurro, após discorrer sobre o complexo de inferioridade do autor, Camargo conclui que ele teria solucionado o problema fingindo-se medíocre, isto é, aderindo, disfarçadamente, às idéias dominantes, enquanto preparava a vingança nos livros. O sucesso no que ele chama de "meio fútil", ou seja, no teatro, garantiria a imunidade ao escritor.

Esses desejos encobertos de vingança, não contra o que lhe haviam feito, mas contra o que lhe pudessem fazer, dado que ele sabia muito bem que seria guerreado se não se fingisse de humilde, é que, talvez, o tenham conduzido, primeiro, para a literatura teatral. ${ }^{10}$

Paralelamente a isso havia a necessidade de se fazer ouvir pela sociedade de seu tempo, com a vantagem de poder presenciar os efeitos de suas idéias através da reação do público. Na esteira do pensamento de Joraci Camargo, Isaac Gondim Filho escreve: “... tinha necessidade de um desabafo e não confiava noutra forma de expor suas idéias, de exercer suas 'vinganças', senão na forma teatral, que é mais direta, mais plástica..."

Considero tais pontos de vista bastante discutíveis. Em primeiro lugar porque questiono a existência do "complexo de inferioridade" que mais de um crítico atribuiu a Machado de Assis. Alguém que se propõe a tornar públicas suas idéias de modo a influir nas de outrem não teria uma auto-estima elevada? Em segundo, não creio que ao fazer teatro o autor se fingisse de medíocre e contemporizador. No meu entender, naquela época, Machado acreditava

10. Machado de Assis e o teatro. Dom Casmurro, 13/03/1943

11. Machado de Assis e o teatro. Diário de Pernambuco, Recife, 29/06/ 1955. 
piamente nos princípios apregoados em suas peças e, se não as fazia melhor, era pela incapacidade que ele mesmo admitiu em célebre carta a Quintino Bocaiúva. Assim, quanto ao motivo da desforra, se houve alguma intenção disso, prefiro o parecer de Joel Pontes, para quem ela se daria apenas no nível da relação do autor com os artistas e o público: ele sentir-se-ia superior dominando-os. Pontes afirma que, exceto Quase ministro, as peças de Machado nada tinham de questionadoras, "Seu teatro adula a sociedade em vez de chibateá-la." e, portanto, como dramaturgo, ele nada teria arriscado.

Para Lúcia Miguel Pereira o teatro foi, na vida de Machado, um pecado de mocidade. A monotonia e as sutilezas psicológicas de suas peças não se prestavam à cena. Seu sucesso na época seria devido à camaradagem, ainda assim relativa, pois, ao submeter suas primeiras comédias à apreciação do amigo Quintino Bocaiúva, o autor teve como resposta juízo que acabou funcionando como uma sentença acatada pela crítica da posteridade; "As tuas comédias são para serem lidas e não representadas"; isso significava negar-lhes a teatralidade. Bocaiúva reconhecia nelas a riqueza de estilo, a beleza literária, a perfeição da linguagem, sentindo-as, porém, frias e insensíveis, sem idéias, sem base.

Por ser considerada inferior em relação ao restante de sua obra, a dramaturgia machadiana ainda não foi suficientemente analisada pela crítica especializada. Talvez isso explique as opiniões conflitantes como, por exemplo, em relação a suas melhores peças. Lúcia Miguel Pereira e José Veríssimo destacam Tu só, tu, puro amor, sendo que o último considera Não consultes médico digna de um Musset; Décio de Almeida Prado diz de Lição de Botânica "... é uma pequena obra-prima de humor romântico, de ironia e delicadeza sentimental"; para Orris Soares e José Aderaldo Castello, Os deuses de casaca afirmam-se como o ensaio de teatro mais importante de Machado de Assis.

Também sobre o dramaturgo não há unanimidade. Se alguns comentaristas chegam ao extremo de liquidá-lo - "... Machado de Assis que foi, sem falta, um dos piores autores teatrais do mundo."; "Poderia quando muito, ter sido um teatrólogo para atenienses. Mas no teatro, os atenienses não chegam a encher duas filas de cadeiras...". ${ }^{13}-$, outros chegaram a endeusá-lo, como é o caso de H. Ferreira da Silva que, em artigo para a revista Teatro ilustrado (ago/ 1959), defende-o da acusação de mau dramaturgo. Para ele o autor foi muito

12. MOREIRA, 1939.

13. CUNHA, Ciro Vieira da. A Gazeta, Vitória, 21/06/1939. 
corajoso fazendo um teatro que ia de encontro às expectativas das platéias da época.

As causas de seu fracasso estariam no mau gosto do público e na falta de atores à altura de seu teatro.

Gilda de Mello e Souza, comentando a encenação de Oprotocolo, ${ }^{14}$ contraria o parecer de Quintino Bocaiúva ao afirmar que a peça lida é monótona, excessivamente literária, representa uma situação banal. Posta em cena por um bom diretor (no caso, Ziembinski), entretanto, revela-se excelente. Quanto a Ruggero Jacobbi, contudo, nem a competência do elenco e do diretor parece tê-lo feito mudar sua opinião sobre o texto, que considera um dos mais fracos de Machado, cheio de "imagens e adjetivos que lembram as gracinhas dos almanaques e das caixas de chocolate, antecipando o pior gosto teatral brasileiro, o de Coelho Neto..." Totalmente diversa, a seu ver, é a peça Lição de Botânica, cuja representação, no teatro Municipal do Rio de Janeiro, mereceu calorosos elogios do crítico Accioly Netto. Não só a montagem de Jacobbi foi elogiada, como também a realizada por um grupo amador. Uma nota na seção de teatro da Gazeta de Notícias (28/10/1955) refere-se à peça nos seguintes termos: "E ainda haverá quem, depois disto, negue teatralidade ou dramaticidade no teatro de Machado de Assis?" Valdemar de Oliveira ${ }^{16}$ também endossa essa opinião e rebate Bocaiúva: "O certo é que, enquanto as comédias de Machado voltam hoje, de vez em quando, à cena, ninguém toleraria a remontagem de uma Os mineiros da desgraça".

O exposto acima deve ser tomado a título de ilustração, pois não é meu propósito aqui julgar ou analisar exaustivamente o teatro machadiano. Apenas comentarei alguns aspectos que interessam para os propósitos deste trabalho.

Da leitura das peças de Machado de Assis pode-se depreender que o intuito civilizador suplantava qualquer possível preocupação em enquadrar-se

14. SOUZA, 1980 , p. $117-122$

15. JACOBBI, 1962, p.58

16. OLIVEIRA, 1967 , p. 41

17. Recentemente (julho de 1997) assisti no Rio de Janeiro à montagem do espetáculo Entre o vermute e a sopa, por Ary Costov, baseado em texto de Artur Azevedo e Machado de Assis. Do último foram encenadas: Lição de Botânica, Antes da Missa e Não consultes médico. 
nos moldes da estética teatral em voga - e que ele defendia em suas críticas. Imprimir valores, ditar regras de comportamento consideradas sensatas, para uma sociedade caracterizada pelo atraso e pela ignorância, foi, parece-me, um dos objetivos do dramaturgo. A meu ver, ele escolheu o gênero dos provérbios dramáticos não só pelo bom gosto e elegância que este emprestaria à comédia brasileira, mas pelo que existia nele de sentencioso (As máximas dos provérbios são geralmente aceitas sem contestação).

Seguindo a tradição cômica, privilegiou a temática amorosa. Das treze peças ${ }^{18}$ que constituem o seu repertório dramático, nove delas têm o amor como tema principal.

O enredo de Hoje avental, amanhã luva (1860) pode ser considerado uma versão atualizada da Cinderela, com a diferença de que, no lugar da ingenuidade e passividade da mocinha injustiçada, coloca-se inteligência e a argúcia de uma criada. O elemento racional substitui a mágica e Rosinha, assim se chama a heroína, muda de classe social ao conquistar o admirador de sua patroa.

Apesar de ser uma "imitação do francês", o fato de Machado tê-la escolhido parece-me significativo. A peça demonstra que vale mais a inteligência, nesse caso a esperteza, do que um nascimento privilegiado. Seguindo um esquema que seria desenvolvido em seus romances, o autor apresentou Rosinha como um a criada especial: estudara em Lisboa no mesmo colégio de sua ama; era, portanto, uma pessoa de espírito e educação; sua condição subalterna era um "erro" a ser corrigido. Corroborando o pensamento liberal, Machado apresentava a ascensão social de uma criada graças ao seu talento e esforço individuais. A frase final, dita pelo criado que ajudou a moça em seus intentos, traduz o espírito da peça: "Desempenhei o meu papel: estou contente! Aquela subiu um degrau na sociedade. Deverei ficar assim! Alguma baronesa não me desdenharia decerto."

Desencantos (1861) discute um tema que estava na ordem do dia: a rivalidade entre os pragmáticos e os sentimentais. Clara é uma viúva disputada por dois homens. Um, Pedro Alves, tem espírito prático e empreende a conquista da amada como um estrategista militar (seu vocabulário o denota); outro, Luís, é um romântico que, na sua timidez, não chega a lutar com a mesma tenacidade pelo amor da viúva. Ao ser preterido, Luís foge para o exterior, de onde volta

18. Odisséia dos vinte anos não chega a ser uma peça teatral; foi classificada na época como "fantasia em ato". 
cinco anos mais tarde, após muito aprender com os orientais. Num baile conhece a filha de Clara e decide casar-se com a moça. Nessa altura, Clara já estava mudada e bastante inclinada a admirar mais os espíritos românticos do que a praticidade monótona do marido deputado. Desencanta-se ao perceber que não é mais alvo de admiração: seu ex-pretendente a substituíra pela filha.

A ridicularização do namorado romântico aparece também no romance $A$ mão e a luva. E este é um tipo que geralmente não atinge seu objetivo. Luís só conquista Clarinha depois de amadurecido, ou seja, quando se torna mais realista. Nessa peça Machado parece querer demonstrar a eficácia do juste millieu, nem os excessivamente pragmáticos se dão bem, nem os excessivamente românticos; há que se ter um equilíbrio entre as duas coisas. E esse equilíbrio só vem com a maturidade, e, ainda assim, para alguns espíritos. D. Clara e Luís modificaram-se com o tempo, atenuando suas tendências radicais; Pedro Alves, porém, continuou o mesmo.

Apesar de conter uma palavra de defesa para com as mulheres "São almas delicadas, mal compreendidas e muito caluniadas" -, a peça traz uma solução no mínimo injusta para a personagem Clarinha. Seu casamento é acertado sem sua participação, ela sequer é consultada a respeito. Ora, não ficava bem numa peça pretensamente moderna retratar um costume que já estava sendo contestado, principalmente nos palcos, há algum tempo.

Em O caminho da porta (1862) também há um triângulo amoroso. Carlota é uma viúva bonita e vaidosa. Dá esperanças a seus admiradores pelo simples prazer de ser cortejada. Nesta peça, baseada no provérbio "Quando não se pode atinar com o caminho do coração, toma-se o caminho da porta", Machado parece ter pretendido fazer uma obra nos moldes do teatro realista. Assim, discute a conduta moral da mulher e suas conseqüências para a sociedade. Contudo, apenas toca de leve nos problemas que as peças da nova escola escancaravam; ele não põe em cena uma prostituta, mas uma namoradeira, com as atenuantes de ser viúva e de pertencer à alta sociedade.

A novidade em relação a suas peças anteriores fica por conta da introdução de um raisonneur: doutor Cornélio. Esse advogado já fora apaixonado por Carlota no passado, mas sua sagacidade o fez ver as verdadeiras intenções da moça ao "dar corda" aos pretendentes. Assim, incumbe-se da tarefa de evitar um desastre abrindo os olhos de Inocêncio, um simplório e ridículo admirador de Carlota, e de Valentim, moço ingênuo e igualmente apaixonado pela viúva. Investido da autoridade conferida pela experiência, ao aconselhar Valentim não disfarça seu temor pela solidez da instituição familiar: 
Ouve-me calado. A que queres chegar com este amor? Ao casamento; é honesto e digno de ti. Basta que ela se inspire na mesma paixão, e a mão do himeneu virá converter em uma só as duas existências. Bem. Mas não te ocorre uma coisa: é que esta mulher, sendo uma namoradeira, não pode tornar-se vestal muito cuidadosa da ara matrimonial.

No final Carlota fica sozinha, pois seus pretendentes, após perceberem suas intenções, desistem da empreitada.

Também n' O protocolo (1862) temos a exposição de um tema caro ao teatro realista, qual seja, a discussão dos problemas da vida conjugal.

Para Jean-Michel Massa, nesta peça Machado teria finalmente afinado com a estética do tempo. José Aderaldo Castello, no entanto, vê apenas uma situação e não uma ação desenvolvida, mais próxima do gosto clássico e do espírito teatral do século XVIII.

De fato, n'O protocolo o autor só esboça o problema da crise conjugal. Há uma intenção de adultério que não se concretiza, pois a esposa, apesar de dar ouvidos aos galanteios de seu admirador, mantém-se fiel ao marido. Os motivos da crise tampouco são convincentes: o marido está entediado com o casamento e reclama dos caprichos da mulher, ela está zangada pelo marido não tê-la levado à casa da madrinha. Ora, não há propriamente conflito, apenas um mal-entendido, facilmente superado com a ajuda de uma prima e após uma conversa entre o casal. Segundo Castello, a ausência de drama, ou de conflito, é determinada pela quebra total de sentimentalidade, pelo riso. Assim, o autor faz de uma situação que poderia ter sido melodramática e enfática, algo espirituoso, leviano, como nos salões.

As forcas caudinas (1864) retomam o ponto de vista apresentado em Desencantos. Tito, o personagem principal, gaba-se de seu ceticismo em relação ao amor, jurando jamais se render a esse sentimento. Emília, uma jovem viúva, pretende provar o contrário, e consegue. O amor por Emília vence as resistências de Tito e ambos terminam juntos.

Uma ode de Anacreonte, editada em 1870, já não é tão otimista em relação ao poder do amor. A peça se passa na Grécia antiga. Lísias, um rico comerciante, e Cleon, um poeta, mostram-se interessados em Mirto, uma prostituta náufraga originária da ilha de Lesbos. Cleon está apaixonado e acredita que o amor irá regenerar Mirto; Lísias, que só acredita nos prazeres físicos, é de outra opinião. Ao final, Mirto decide-se pelo rico comerciante, seduzida pelas ofertas de luxo e riqueza, e Cleon parte desiludido com a traição do amigo e de sua amada. 
A peça repousa no lugar-comum, isto é, a mulher perdida não passa de uma interesseira; os poetas são uns ingênuos em acreditar no poder regenerador do amor; o ingênuo sempre leva a pior. Enfim, endossa o moralismo apregoado pela estética do século XIX. Os homens devem escolher mulheres honestas para se casarem; as outras não são confiáveis e fatalmente os farão sofrer (Talvez o autor tenha querido mostrar que o interesse material não é coisa de sua época, sempre existiu). O mérito da peça, creio, está nos versos bastantes fluentes do texto.

Outra peça cuja ação situa-se no passado é Tu só, tu, puro amor, escrita sob encomenda para comemorar o tricentenário de Camões em 1880. Trata dos amores palacianos de Camões com a camareira da rainha de Portugal, D. Catarina de Ataíde. O poeta conquistou a jovem com seus belos versos e seu jeito impetuoso. Caminha, mais velho que Camões, também amava a bela Catarina e, sabendo que o pai da moça desaprovava o romance com o rival, trata de denunciá-lo. D. Antônio de Lima, pai de Catarina, pede ao rei para desterrar Camões a fim de separá-lo de sua filha, no que é atendido; resignado à sua sorte Camões parte para o desterro na Ásia.

Embora essa não seja uma peça típica, das que se representavam na época, prende atenção por seu enredo romanesco. A figura de Camões surge-nos bastante simpática. Os diálogos são ágeis. Machado não se deixa levar pelo palavreado fácil que poderia ser atribuído à verborragia do poeta. O conflito em torno do tema do amor impossível é explorado com comedimento, isto é, os amantes sofrem, mas não chegam a se suicidar, embora o degredo para Camões possa ser entendido como uma morte.

Não consultes médico (1896) é uma comédia em torno do provérbio grego. "Não consultes médico; consulta alguém que tenha estado doente". D. Leocádia é uma senhora da sociedade que se diz médica de doenças morais. Em seu currículo consta a cura de sua sobrinha Adelaide e de Magalhães. Ambos andavam aborrecidos e tristes e ela curou-os. A peça inicia-se com o casal preparando-se para viajar para a Grécia. D. Leocádia pede para que levem junto sua filha Carlota, desiludida por um namoro frustrado com um certo capitão de engenharia. Nesse ínterim, aparece na residência de Magalhães, Cavalcante, um amigo. Bastante acabrunhado devido a uma desilusão amorosa, o rapaz pensa em se tornar monge enclausurado. D. Leocádia, após se inteirar de seu estado, receita-lhe uma viagem à China. Quando já estava convencido de que essa seria a melhor solução para o seu mal, Cavalcante descobre que Carlota também padecia por amor. Apaixonam-se e marcam o casamento. 
Esta comédia de salão traz comentários engraçados e a ironia típica machadiana. A novidade fica por conta de sua evidente modernidade. Apesar de apresentar uma velha alcoviteira, esta vem com as atenuantes de pertencer à alta sociedade e da autoridade científica, pois é "médica". Os Magalhães formam um casal moderno que dialoga e se respeita mutuamente. O ex-namorado de Carlota é engenheiro naval. Além disso, o cosmopolitismo dessas personagens é evidenciado pelos lugares mencionados na peça: os Magalhães planejam conhecer a Grécia e o marido já conhece pelo menos a Guatemala, onde servira no corpo diplomático; a rival de Carlota era uma viúva espanhola; Cavalcante amara uma peruana e pergunta a D. Leocádia se ela não conhece nenhum cardeal em Roma; aparece também a referência à China e um provérbio grego dá mote à peça.

Lição de Botânica (1906) é outra peça com evidentes índices de modernidade. Se em Uma ode de Anacreonte o amor sai derrotado no embate com o dinheiro, aqui ele impõe-se sobre a ciência.

D. Leonor tem duas sobrinhas bonitas. Helena, uma jovem viúva, e Cecília, mais moça e apaixonada pelo vizinho, sobrinho de um botânico sueco. Este é contra o namoro, pois acha que a ciência exige dedicação exclusiva. Assim, pede a D. Leonor que feche a porta de sua casa ao sobrinho. Helena, para ajudar a irmã, finge-se interessada em ter aulas de botânica com o tio do pretendente de Cecília. Entusiasmado com o interesse de Helena pela ciência, o barão acaba apaixonando-se por ela. Esta, com a inteligência e o desembaraço próprios da viúvas machadianas, acaba mostrando ao botânico que sua extrema dedicação à ciência não passava de defesa contra o amor. Ele mesmo reconhece: “...o mundo intelectual é estreito para conter o homem todo; ...a vida moral é uma necessidade do ser pensante".

Um dos propósitos dessa peça é criticar o entusiasmo cego pela ciência e pelas coisas estrangeiras que tomava conta do país. Uma fala de D. Leonor deixa isso patente: "- Botânico e sueco: duas razões para ser gravemente aborrecido." Mas o barão (a ciência) rende-se ao amor da interessante Helena. Haveria alguma alusão à heroína de Tróia, por quem todo um exército sucumbira?

Se, por um lado, a excessiva amenidade e ausência de ação dessas peças distanciam-nas do espírito teatral da época, por outro, há que se louvar o tratamento dispensado à mulher. Com algumas exceções, as protagonistas do teatro machadiano são mulheres fortes e inteligentes. A predileção pelas viúvas talvez se explique pelo desejo de tornar verossímil a presença de uma personagem mulher e independente. Mesmo a jovem esposa de Oprotocolo está 
longe de ser uma mulher submissa. Elisa, em conversa com sua prima mais jovem e solteira, adverte:

- Quero entretanto, instruir-te de uma coisa. ... Essas asas [a liberdade dos homens] os levam a jantar fora, a dormir fora, muitas vezes a amar fora. A essas chamam enfaticamente: o nosso direito!

...Uma santa zangar-se-ia como eu. Para caprichoso, caprichosa!

Machado sempre teve em alta conta o sexo feminino. Foi um grande incentivador da maior participação da mulher, tanto na vida conjugal, como cultural e social. Portanto, causa-me estranheza que tenha publicado duas pecinhas tão chauvinistas como O bote de rapé e Antes da missa, ambas de 1878. A primeira enfatiza a vaidade e o egoísmo femininos: Tomé pede a Elisa que lhe compre um bote de rapé. Esta vai à cidade, compra tudo o que vê pela frente, mas se esquece da encomenda do marido. A outra aborda o lado mexeriqueiro da mulher: D. Laura, a caminho da missa, encontra-se com a amiga D. Beatriz. Ambas conversam sobre a festa ocorrida na casa da primeira, à qual a outra não fora por motivo fútil. D. Laura faz comentários, nem sempre bondosos, sobre todos os freqüentadores do baile e sobre outros conhecidos também.

Em Quase ministro (1863) e Os deuses de casaca (1864) ${ }^{19}$ não há mulheres; isto valeu um protesto do autor, quando da publicação da última. Nessas peças a crítica recai sobre a hipocrisia da sociedade da época. O autor aproveita o tema para desenvolver personagens tipos. Na primeira, são os bajuladores interesseiros que cercam o protagonista, cotado para assumir um ministério. Na segunda, os deuses do Olimpo transformados em homens assumirão os papéis mais representativos da sociedade.

O autor também irá aproveitar o enredo dessas peças para tornar mais explícita sua militância pela causa teatral. Assim, em Quase ministro introduz a discussão sobre as subvenções ao teatro lírico através do personagem Agapito, que reivindica a verba com os seguintes argumentos:

19. Esta peça teve Olavo Bilac no papel de Epílogo, quando de sua representação pelos membros da Sociedade Brasileira de Homens de Letras. Cf. Jornal Meio Dia, Rio de Janeiro, 27/12/1939. 
Há uma porção de razões para demonstrar a necessidade de um teatro lírico. Se o país é feliz... a música confirma as comoções de felicidade. Se o país é infeliz... a música adoça as dores. Se o país é dócil, é bom que ouça a música, para nunca se lembrar em ser rebelde. Se o país é rebelde... a música adormece os furores e produz a brandura. Em todos os casos a música é útil. Deve ser até um meio de governo.

Mas a verdadeira razão, que Agapito confessa em voz baixa, é o seu namoro com a prima-dona da companhia. Ora, deixando a defesa da subvenção ao cargo de um personagem "malandro", o autor condena-a, deixando implícita uma posição favorável ao teatro dramático.

N'Os deuses de casaca o personagem Epílogo lamenta o destino dos deuses e coloca a arte como a única coisa capaz de resgatar sua grandeza:

Se o tempo sepultou Eros, Minerva e Marte

Uma coisa os revive e os santifica: a arte.

Os momentos em que o autor levanta a voz em defesa da arte são mais freqüentes na sua crítica do que na dramaturgia; mas os há.

As peças de Machado de Assis não chegaram a provocar o efeito esperado de uma obra do teatro realista. Ele jamais escreveu algo como História de uma moça rica, sequer um drama abolicionista - ainda que a bilheteria de duas de suas comédias tenha sido destinada à libertação de escravos. Porém, não se pode negar a importância de sua contribuição também como autor teatral no período de maior efervescência do nosso teatro do século XIX.

A partir da década de 1870 Machado passa a dedicar-se mais à ficção, diminuindo sensivelmente sua atividade como crítico dramático. O teatro, porém, estará sempre presente, de maneira explícita ou subliminar, nos romances e contos que irá produzir ao longo da vida.

A título de ilustração, vejamos como isso se dá nos contos. Se em alguns deles o teatro é apenas um mote para iniciar a narrativa (Suje-se gordo; Uma noite), em outros sua presença é inerente à estrutura da obra, ora auxiliando na caracterização das personagens, ora compondo o ambiente, ora atuando como tema para discussões mais filosóficas, como, por exemplo, o efeito da arte sobre os indivíduos.

No primeiro caso enquadram-se os contos em que a preferência teatral da personagem reflete a sua personalidade. Jorge, de Miss Dollar; Luís Soares, do conto homônimo; Vasconcelos e Gomes de O segredo de Augusta, são 
caracterizados como 'bons vivants', frívolos e de caráter duvidoso; freqüentam o Alcazar Lírico. Esse teatro aparece em algumas crônicas de Machado como tão prejudicial à arte dramática quanto os elementos acima são prejudiciais à sociedade. $\operatorname{Em} D$. Jucunda, a personagem-título não é propriamente mau-caráter, mas é egoísta e vaidosa; freqüenta o Imperial Teatro D. Pedro II, como todas as ricas senhoras de seu tempo. O escritor tampouco nutria grandes simpatias por esse teatro.

No conto Miloca, o pai da heroína, pequeno comerciante decadente de um bairro modesto do Rio de Janeiro, adorava dramalhões. A filha, pretensiosa e com gosto apurado no colégio de moças ricas, aborrecia-se com tais peças. Fortunato, de A causa secreta, apesar de estar socialmente acima do pai de Miloca, levado pelo sadismo doentio, vai ao Teatro de S. Januário ver um "...dramalhão, cosido à facada, ouriçado de imprecações e remorsos." O protagonista de Verba testamentária, por ser extremamente invejoso, só prestigiava o que havia de pior. Gostava do João Caetano dos primeiros tempos, ou seja, do exagerado intérprete de dramas românticos de mau gosto, gênero também cultivado pelo enfadonho major Lopo Alves, de A chinela turca. Esse, chegando à casa do bacharel Duarte num momento impróprio (ele se preparava para ver a namorada), insiste em ler seu drama para o amigo, que adormece durante a leitura. Ao final, o rapaz reconhece que só não teve sua noite transformada num desastre total graças ao sonho que teve enquanto o major lia o drama. Sonho com lances de dramalhão, é verdade, porém mais "original" que a peça do major.

Nem todos os personagens machadianos iam ao teatro movidos por uma preferência "estética". No conto O Capitão Mendonça o narrador decide ir ao S. Pedro para distrair-se de uns "arrufos de amor". No decorrer da representação de um drama ultra-romântico, dorme e tem um pesadelo, com lances tão inverossímeis quanto os da peça. Após o vexame de ser despertado pelo porteiro do teatro, sai "protestando não recorrer, em casos de arrufo, aos dramas ultraromânticos: são pesados demais". ${ }^{20}$ Também o casal de Letra vencida, envolto no tédio de um casamento sem emoções, vai ao teatro por desfastio. No conto Sales, a personagem-título, homem de muitas idéias e poucas realizações, expõe no Teatro de Santa Isabel, em Recife, seus planos sobre um grande empreendimento ao futuro sogro.

O Teatro Lírico aparece nos contos de Machado como um espaço democrático, freqüentado pela elite, pelos remediados (Vênus! Divina Vênus!;

20. ASSIS, 1956, p. 182. 
Questões de maridos) e por estudantes pobres (Uma por outra). Uns vão por gostar sinceramente de música, outros à caça de bons partidos. Dessa forma, o Lírico também figura como local de sedução. Em D. Paula, Machado descreve o ambiente propício às abordagens amorosas "...o corredor, os pares que saíam, as luzes, a multidão, o rumor das vozes...”. No Teatro Lírico, Venancinha, sobrinha de D. Paula, recebe uma declaração de um admirador e fica bastante impressionada. Um detalhe: ela é casada. Esta também é a condição da heroína de Confissões de uma viúva moça, cortejada no mesmo teatro por Emílio, um rapaz avesso ao casamento. Nesses dois casos o adultério não chega a se concretizar, mas fica claro o perigo que pode representar a simples ida de uma senhora bonita ao Teatro Lírico.

O teatro aparece como local de sedução também nos contos $O$ programa e A desejada das gentes. No primeiro, Romualdo percorre todos os teatros à procura da viúva rica por quem se interessara. No outro conto, o narrador refere-se às conversas dos rapazes no teatro sobre os bons partidos. Quintília, a desejada das gentes por seu dinheiro e beleza, é indiferente a todos os seus admiradores e, ao que parece, vai ao teatro unicamente para ver o espetáculo. O mesmo parece suceder com Marcelina ( $A$ chave), a filha do Major Bastos. Inteligente e impetuosa, em suas conversas com o pretendente, Luís Bastinhos, declara gostar muito de teatro, tem lembranças do Tamberlick e do João Caetano.

Diferentemente das duas personagens acima, Malvina, de Entre duas datas, vai ao teatro para ser vista. Sua vaidade leva um admirador a desistir de cortejá-la: "...pareceu-lhe que ela voltava a cabeça para todos os lados com muita preocupação do efeito que estivesse causando." O teatro como uma vitrine onde a mulher se exibe aos olhos da sociedade é abordado, também, em A senhora do Galvão. Neste conto, o marido adúltero, para agradar a mulher e dissipar-lhe as desconfianças, leva-a ao Teatro Provisório para ver os Lombardos. A ópera podia não agradar muito, mas Galvão sabia o quanto Maria Olímpia gostava de ir a teatros exibir sua beleza. ${ }^{21}$

Já Raquel, personagem de Ponto de vista, não se importa em ser vista, vai ao teatro para ver as pessoas. Observadora, relata as "notícias" da Corte para a amiga que vive na província:

21. Em crônica de 20/10/1859, Machado comenta a indiferença do público à época de sua representação. Cf. CT, p.51. 
...[estive] no Ginásio, onde fui ver uma peça nova, muito falada e muito insípida.

Sabe quem estava lá? A Mariquinhas com o noivo no camarote, e o enteado também... Não se pode imaginar como ela parecia contente, como ela conversava com o noivo! E olhe que de longe, à luz do gaz, o tal velho é quase tão moço como o filho. ${ }^{22}$

Se para alguns o conteúdo das peças era o que menos interessava no teatro, para outros ele era importante a ponto de influenciar diretamente suas vidas. Esse parece ser o caso de Cecília, protagonista de Curta bistória e de Marocas, de Singular ocorrência.

Ambos falam da interferência da arte na vida. Com algumas variações, esse tema é mais ou menos recorrente na obra de Machado de Assis. Já vimos como em A chinela turca a fantasia se mistura com a realidade e salva o protagonista de uma noite maçante. Ao comentar essa metáfora sob o ponto de vista filosófico, Paul Dixon ${ }^{23}$ afirma que a intenção do autor seria mostrar o mundo como um grande texto falho, cujas lacunas são preenchidas pelos sonhos humanos (1992: 106). Curta história é um bom exemplo disso.

A paixão de Cecília pelo namorado era de causar admiração a quem os conhecesse. Ela, uma jovem bonita e inteligente; ele, alguém absolutamente insípido, incapaz de inspirar simpatia, muito menos amor. Mas a moça não pensava assim, "...amava aquele único namorado, Juvêncio de tal." (o grifo é meu). E seu amor aumentou após assistir o ator Rossi interpretar Romeu no teatro. Cecília projetou-se em Julieta, ouvia as palavras de Romeu como se fossem dirigidas a ela, "Era Romeu que a amava". Ao sair do teatro, não olhou para os rapazes, como fez sua prima; só pensava em Romeu. Em casa, sonhou, almoçou e jantou com ele, nenhuma vez se lembrou de Juvêncio. Porém, quando ele apareceu, recebeu-o comovida. Nesse momento o narrador observa: "Isto quer dizer que todo amado vale um Romeu". Meses depois casaram-se e provavelmente foram felizes, graças à extraordinária capacidade de Cecília em adaptar seus sonhos românticos à triste realidade da mulher sem fortuna da época. É importante lembrar que Juvêncio era o único e além disso tinha algumas apólices.

22. MACHADO DE ASSIS, 1992, Vol. 3, p. 242

23. DIXON, 1992, p. 106. 
Curta história é um conto muito bem estruturado - como a maioria dos de Machado - em que não apenas a personagem, mas também o autor mistura realidade e ficção. O narrador começa reportando-se à passagem do ator Rossi pelo Rio de Janeiro, fato realmente ocorrido em 1871 e registrado por Machado de Assis em crônica altamente elogiosa na Semana Ilustrada (25/6/1871).

Como fazia em sua Crítica Teatral da revista O Espelho, o autor dirige-se a uma "leitora" virtual, ou não, no caso de o conto ser lido por uma contemporânea sua. E, parece-me, era preferível que fosse assim, dada a intenção do narrador em integrar ao máximo a leitora à narrativa. Se, como Cecília, ela também viu o ator Rossi; se também se casou com um homem "real" e não "ideal"; se conseguiu ver na vida da protagonista a sua própria vida; poderá transpor a barreira que separa a realidade da ficção e sentir-se tão personagem do conto quanto Cecília da peça de Shakespeare. Essa estratégia para promover a identificação da leitora com a personagem fica evidente no paralelismo da frase: “... assim pensava a leitora, assim pensava uma D. Cecília...”.

Outro aspecto explorado pelo narrador é a duplicidade de sentido de algumas proposições. Por exemplo: "Naquele tempo esta Cecília tinha dezoito anos e um namorado. A desproporção era grande..."; a princípio a desproporção refere-se ao número de anos em relação ao de namorados, mais tarde veremos que ela também se aplica ao casal, isto é, ela interessantíssima e ele absolutamente medíocre, conforme já mencionamos acima. As amigas da jovem não se conformavam com sua paixão por Juvêncio e acreditavam que os céus estavam lhe preparando um namorado melhor. Novamente o narrador lança mão do duplo sentido:

"Apareceu Rossi, revolucionou toda a cidade." Além do sentido literal, a frase também pode aludir ao fato de ter sido o ator Rossi o "arcanjo" que levou Cecília ao paraíso, ou melhor, salvou-a do inferno.

Outro item que conota duplicidade diz respeito à própria personalidade da heroína. O narrador a define como romanesca; mas sua história nos mostra que, se ela tinha um lado sonhador, este não chegava ao extremo de provocar a recusa de pretendentes reais pela espera de um príncipe encantado, que poderia não chegar (suas amigas talvez o fizessem). Mesmo o desajeitado Juvêncio torna-se um personagem duplo. Graças à imaginação da noiva, transformase no belo e elegante Romeu.

Se em outros momentos de sua obra Machado explora a semelhança da vida com o teatro, em Curta história ele nos mostra o quanto ela é diferente, 
oposta mesmo, embora ambos se complementem. No conto em questão, a arte fornece à heroína a dose de fantasia necessária para suportar uma realidade demasiadamente prosaica.

Outro momento de integração teatro/vida ocorre no conto Singular ocorrência. Marocas, uma prostituta pobre e analfabeta, deixa a profissão para dedicar-se exclusivamente a Andrade, por quem se apaixona perdidamente. Um dia, porém, sem um motivo aparente, entrega-se a um desconhecido. Apesar da decepção, Andrade releva o acontecido. Reconciliados, Marocas mantém-se fiel a ele até depois de sua morte.

O teatro aparece em dois momentos cruciais da vida de Marocas. No dia em que conhece Andrade vai ao Ginásio assistir $A$ dama das camélias e chora copiosamente, certamente identificando-se com a heroína redimida pelo amor. Outro momento se dá quando Andrade, que era casado, a deixa só para viajar com a família. Marocas janta com o retrato do amante, a exemplo da solitária Sofia Arnoult de Janto com minha mãe, peça que vira semanas atrás, também no Ginásio Dramático.

A despeito da identidade de situação, o autor não dá a Marocas o mesmo destino trágico das heroínas do palco - afinal, trata-se de uma moça simples do Rio de Janeiro, ignorante do luxo e da coquetterie parisiense. Porém deixa claro que, tanto para Marocas como para Cecília, o teatro não era uma simples diversão, mas o lugar de onde elas tiravam inspiração e forças para suportar a realidade ingrata que se apresentava à mulher pobre e livre na sociedade de então. Em Singular ocorrência, principalmente, pode-se dizer que o teatro realiza o ideal daquela geração de críticos adeptos do realismo à qual pertencera Machado de Assis.

Em outros contos, o autor se utiliza do teatro para exemplificar situações de popularidade, - em Cantiga de esponsais, compara o sucesso de mestre Romão ao dos atores João Caetano e Martinho -; ou para explorar as contradições humanas, - no conto Um dístico, a personagem divide-se entre o sagrado e o profano, ao exercer a profissão de porteiro de teatro, à noite, e irmão das almas durante o dia. Em Mariana o teatro é exemplo para uma reflexão sobre a gratuidade em arte: Evaristo consola o amigo, arrasado com o fracasso de sua peça em Paris, dando a entender que, em teatro, o sucesso independe da qualidade da obra e fica mais ou menos a cargo da sorte: "Há peças que caem. Há peças que ficam no repertório." No conto $A$ mulher de preto, o autor denuncia o expediente desonesto de um dramaturgo medíocre que publica, sob pseudônimo, 
uma crítica elogiosa sobre sua própria peça. Também se pode ler nesse episódio um alerta sobre a não confiabilidade da imprensa. Àquela altura Machado não era mais o jovem de 1859, para quem o jornal era a suprema encarnação da verdade.

O teatro aparece também nos seus romances da maturidade, considerados o melhor de sua obra. Em Esaú e Jacó e Dom Casmurro tem-se uma de suas metáforas preferidas, qual seja, a comparação da vida com o espetáculo teatral. Nesse último, o fato de o ciumento Bentinho assistir a Otelo, de Shakespeare, também auxilia na composição do clima de suspense do romance. Em Quincas Borba o casal Sofia e Palha vai ao teatro para exibir-se à sociedade, sendo que o marido sequer apreciava esta arte. Nas Memórias póstumas de Brás Cubas o teatro é uma das referências para a caracterização de Damasceno, um personagem secundário e meio ridículo, que se acha importante mas não passa de um parente pobre de Cotrim; tem duas qualidades que o distinguem: é extremamente prolixo e gosta muito de teatro. Ao descrevê-lo, Machado retrata a relação do público médio, ou menos informado, com a cena:

...logo que chegou foi ao teatro de São Pedro, onde viu um drama soberbo, a Maria Joana, e uma comédia muito interessante, Kettly, ou a volta à Suiça. Também gostara muito da Deperini, na Safo, ou na Ana Bolena, não se lembrava bem. Mas a Candiani! sim, senhor, era papa-fina. ${ }^{24}$

Haveria nessa última observação uma auto-ironia? É bem possível, pois o Machado que escreveu Brás Cubas talvez visse algo de ridículo na tietagem que praticara na juventude.

Abstract: The theater was one of first literary passions of Machado de Assis. For it, he fought through the press, at Playwrights' Conservatory, as playwright and as writer. This article aims to demonstrate the moments and how much Machado de Assis has engaged bimself in the fight to modernize brazilian society through the theater.

Key words: Brazilian literature; Theater; Machado de Assis.

24. MACHADO DE ASSIS, 1992, v. 1, p. 600. 


\section{Referências Bibliográficas}

BALZAC, Honoré de. Ilusões perdidas. Trad. Ernesto Pelanda e Mário Quintana. São Paulo: Abril Cultural, 1981.

BARRETO FILHO. Introdução a Machado de Assis. Rio de Janeiro: Agir, 1947.

BROCA, Brito. Machado de Assis e a política e outros estudos. Rio de Janeiro: Organização Simões Editora, 1957.

CUNHA, Ciro V. da. A Gazeta. Vitória, 21 jun. 1930.

DIXON, Paul. Os contos de Machado de Assis: mais do que sonha a filosofia. Porto Alegre: Movimento, 1992.

JACOBBI, Ruggero. O espectador apaixonado. Porto Alegre: Fac. de Filosofia da UFRG, 1962.

MACHADO DE ASSIS, Joaquim Maria. Obra Completa. Rio de Janeiro: Editora Nova Aguilar, 1992. v. 1, 2, 3.

MACHADO DE ASSIS, Joaquim Maria. Crítica teatral. Rio de Janeiro: M. Jackson Inc. Editores, 1944.

MACHADO DE ASSIS, Joaquim Maria. Crítica literária. Rio de Janeiro: M. Jackson Inc. Editores, 1946.

MACHADO DE ASSIS, Joaquim Maria. Crônicas. Rio de Janeiro/São Paulo: Livro do mês S. A./M. Jackson Inc. Editores, 1961-2. v. 1, 2, 3, 4.

MACHADO DE ASSIS, Joaquim Maria. Teatro completo. Rio de Janeiro: MEC/SNT, 1982. v. 6.

MACHADO DE ASSIS, Joaquim Maria. Contos sem data. Rio de Janeiro: Civilização Brasileira, 1956.

MAGALHÃES Jr., Raimundo. Machado de Assis desconbecido. Rio de Janeiro: Civilização Brasileira, 1955.

MASSA, Jean-Michel. A juventude de Machado de Assis (1839-1870). Ensaio de biografia intelectual. Rio de Janeiro: Civilização Brasileira/Conselho Nacional de Cultura, 1971.

MOREIRA, Álvaro. Sobre teatro. Diário da Manhã, Niterói, 19/08/1939.

OLIVEIRA, Valdemar de. Eça, Machado, Castro Alves, Nabuco e o teatro. Recife: Imprensa Universitária/UFPE, 1967.

PESSANHA PÓVOA. História e tradições da cidade de São Paulo. 2. ed. Rio de Janeiro: José Olympio, 1954. v. 2.

SOUZA, Gilda de M. e. Machado em cena. In: Exercícios de leitura. São Paulo: Duas Cidades, 1980. 